\title{
Sistem Produksi Kerajinan Bambu Wulung Perpektif Ekonomi Islam (Studi Kasus Industri Kerajinan Bambu Wulung Desa Kemutug Kidul, Baturraden, Banyumas)
}

\author{
Nurlaeli Destiyanti \\ Institut Agama Islam Negeri Purwokerto \\ email: nurlaelidestiyanti@gmail.com
}

Manuscript History:

Received: 23-03-2021

Accepted: 21-04-2021

Published: 22-04-2021

\begin{abstract}
The production system is a collection of subsystems that interact with each other by transforming production inputs into production outputs. This type of research used to achieve the objectives of this study is field research. The analytical method used in this research is descriptive analysis method. Based on research results from Islamic economic analysis. The three wulung bamboo craft industries have partly implemented a production system in accordance with an Islamic economic perspective. Input can be seen from natural resources or raw materials, capital resources and human resources, which are used according to needs and are best utilized and in accordance with Islamic laws. The production process carried out by the three wulung bamboo craft industries in Kemutug Kidul Village is carried out in accordance with the planned stages. The output can be seen from the products produced by the bamboo wulung handicraft industry in the village of Kemutug Kidul, Baturraden, of good quality. This is evidenced by the high response from the wider community.
\end{abstract}

Keywords: production system; bamboo wulung craft; islamic economy

\begin{abstract}
Abstrak
Sistem produksi merupakan kumpulan dari subsitem-subsistem yang saling berinteraksi dengan mentransformasikan input produksi menjadi output produksi. Jenis penelitian yang digunakan untuk mencapai tujuan penelitian ini adalah penelitian lapangan (Field Research). Dengan metode analisis yang digunakan dalam penelitian ini adalah metode deskriptif analisis. Berdasarkan hasil penelitian dari analisis ekonomi Islam. Ketiga industri kerajinan bambu wulung sebagian sudah menerapkan sistem produksi sesuai dengan perspektif ekonomi Islam. Pada imput dapat dilihat dari sumber daya alam atau bahan baku, sumber daya modal dan sumber daya manusia, yang pemanfaatannya digunakan sesuai dengan kebutuhan dan didayagunakan sebaik-baiknya serta sesuai dengan hukum-hukum Islam. Proses produksi yang dilakukan oleh ketiga industri kerajinan bambu wulung Desa Kemutug Kidul dilakukan sesuai dengan tahapan-tahapan yang telah direncanakan. Pada output dilihat dari produk yang dihasilkan oleh industri kerajinan bambu wulung Desa Kemutug Kidul, Baturraden berkualitas baik. Hal ini dibuktikan dengan respon yang tinggi dari masyarakat luas.
\end{abstract}

Kata Kunci: sistem produksi; kerajinan bambu wulung; ekonomi islam 


\section{PENDAHULUAN}

Di Indonesia sebagai negara yang sedang berkembang, kegiatan pertanian masih merupakan sektor yang dominan. Perubahan dari perekonomian agraris menjadi perekonomian industri merupakan tranformasi struktural dalam perekonomian suatu negara. Sektor industri kecil merupakan jembatan transformasi struktural mengingat karakteristik yang dimiliki industri kecil tersebut. Industri adalah kegiatan ekonomi yang mengolah bahan mentah, bahan baku, barang setengah jadi dan atau barang jadi menjadi barang yang nilainya lebih tinggi untuk penggunaanya, termasuk kegiatan rancang bangun dan perekayasaan industri (Dwiyanto, 1996).

Sumber daya alam atau bahan baku menjadi pendukung proses produksi di industri kerajinan bambu wulung Desa Kemutug Kidul, Baturraden, Banyumas. Bahan baku utama yang digunakan adalah bambu wulung yang dipesan dari pemasok yang berasla dari Kebumen, Purworejo, Bumiayu, Tegal dan Karang Pucung. Walaupun bukan penghasil bahan baku bambu wulung namun Desa kemutug Kidul kecamatan Baturraden sudah terkenal sejak tahun 1980an menjadi sentra kerajinan bambu dan menjadikan desa ini menjadi salah satu sentra industri bambu di Kabupaten Banyumas.

Produk yang dihasilkan dari industri bambu wulung tidak hanya berfokus pada satu macam jenis saja tetapi beraneka ragam seperti meja, kursi hingga pembatas ruangan. Kerajinan industri bambu wulung Desa Kemutug Kidul sudah mendapatkan respon yang baik dari masyarakat luas. Hal ini dibuktikan dengan pemasaran yang sudah menembus sampai keluar pulau jawa, seperti Sumatera, Kalimantan dan Sulawesi. Omset yang dicapai setiap bulannya sebanyak 600-700 kerajinan bambu wulung. Selain kualitas yang baik, kekhasan warna hitam keunguan bambu wulung juga menjadi daya tarik tersendiri untuk para konsumennya.

Persaingan yang semakin ketat dalam dunia usaha dan semakin maju cara-cara yang dikembangkan untuk mencapai tujuan dan sasaran secara efektif dan efisien. Dalam menghadapi persaingan dunia industri, para pelaku industri harus siap dan kompetitif. Oleh karena itu kerajinan bambu wulung yang ada di desa Kemutug Kidul Baturraden harus selalu berinovasi untuk meningkatkan daya saing. Selain harus selalu berinovasi industri kerajinan juga harus selalu mempertahankan kualitas dari kerajinan yang diproduksi, maka industri kerajinan harus memperhatikan mutu bahan baku yang digunakan dan memperhatikan dengan teliti setiap proses produksi yang dilakukan.

\section{METODE PENELITIAN}

\section{Jenis Penelitian}

Jenis penelitian ini adalah penelitian lapangan, yaitu suatu penelitian yang dilakukan dilokasi penelitian dengan mengadakan pengamatan tentang suatu fenomena dalam suatu keadaan alamiah(Moleong, 2008). Penelitian lapangan merupakan penelitian mendalam mengenai unit sosial tertentu yang hasilnya merupakan gambaran yang lengkap dan 
terorganisasi baik mengenai unit tersebut. Tergantung kepada tujuannya, ruang lingkup penelitian itu mungkin mencakup keseluruhan siklus kehidupan atau hanya segmensegmen tertentu saja(Suryabrata, 1990).

\section{Subjek dan Objek Penelitian}

Di dalam sebuah penelitian, subjek penelitian merupakan sesuatu yang kedudukannya sangat sentral karena pada subjek penelitian itulah data tentang variabel yang diteliti berada dan diamati oleh peneliti(Arikunto, 1992). Di Desa Kemutug Kidul terdapat 16 rumah tangga yang memproduksi kerajinan bambu wulung. Dalam penelitian ini mengambil tiga pemilik industri kerajinan bambu wulung di Desa Kemutug Kidul Kecamatan Banturraden sebagai subjek penelitian yaitu, Bapak Sahid, Bapak Bambang dan Bapak Triyoko. Sedangkan objek penelitian utamanya adalah produksi pada industri kerajinan bambu wulung di Desa Kemutug Kidul, Baturraden, Banyumas.

\section{Metode Pengumpulan Data}

Adapun metode pengumpulan data yang digunakan adalah:

a. Interview (Wawancara)

Wawancara digunakan sebagai teknik pengumpulan data, apabila peneliti ingin melakukan studi pendahuluan untuk menemukan permasalahan yang harus diteliti dan juga apabila peneliti ingin mengetahui hal-hal dari responden yang lebih mendalam dan jumlah respondennya sedikit/kecil. Wawancara dapat dilakukan secara terstruktur maupun tidak terstruktur.

b. Dokumentasi

Metode dokumentasi yaitu mencari data mengenai hal-hal atau variabel yang berupa catatan, transkrip, buku, surat kabar, majalah, prasasti, notulen rapat, legger, agenda dan sebagainya.

c. Observasi

Observasi atau pengamatan adalah pengamatan dengan menggunakan indera penglihatan yang berarti tidak mengajukan pertanyaan-pertanyaan(Soehartono, 2000).

\section{TINJAUAN PUSTAKA}

\section{Perencanaan Sistem Produksi}

Pelaksanaan kegiatan produksi dalam suatu perusahaan diperlukan serangkaian unit yang terpadu dan saling menunjang untuk pelaksanaan proses produksi, yang disebut dengan sistem produksi. Kegiatan-kegiatan yang dilaksanakan dalam perusahaan ini akan selalu saling berhubungan antara kegiatan yang satu dengan kegiatan yang lainnya. Oleh karena itu, guna memperoleh hasil yang sebaik-baiknya, perlu untuk diadakan perencanaan yang cermat dan teliti dari system produksi yang akan digunakan oleh perusahaan tersebut. Adapun beberapa 
hal yang perlu dalam perencanaan system produksi ini adalah perencanaan produk, perencanaan lokasi pabrik, perencanaan letak fasilitas produksi, perencanaan lingkungan kerja dan perencanaan standar produksi(Ahyari, 1999).

\section{Sistem Produksi}

Dalam melaksanakan fungsi-fungsi produksi dengan baik, diperlukan suatu rangkaian kegiatan yang nantinya akan membentuk suatu sistem yang dinamakan sistem produksi. Kegiatan-kegiatan yang dilaksanakan dalam perusahaan ini akan selalu saling berhubungan antara yang satu dengan kegiatan lainnya. Oleh karena itu, untuk memperoleh hasil yang semaksimal mungkin, perlu diadakan perencanaan yang cermat dan teliti dari sistem produksi yang akan digunakan oleh perusahaan tersebut.

(Et.al, 2019) Sistem produksi merupakan kumpulan dari subsitem-subsistem yang saling berinteraksi dengan mentransformasikan input produksi menjadi output produksi. Input produksi ini dapat berupa bahan baku (material), tenaga kerja (man), modal (money), mesin (machine), metode (method), energi (energy) dan informasi (information). Sedangkan output produksi merupakan suatu produk yang dihasilkan baik berupa barang ataupun jasa. Beberapa elemen yang termasuk dalam sistem produksi adalah produk perusahaan, lokasi pabrik, letak dan fasilitas produksi yang dipergunakan dalam perusahaan, lingkungan kerja karyawan, serta standar produksi yang berlaku dalam perusahan tersebut (Karamoy, Tumade, \& Palandeng, 2016).
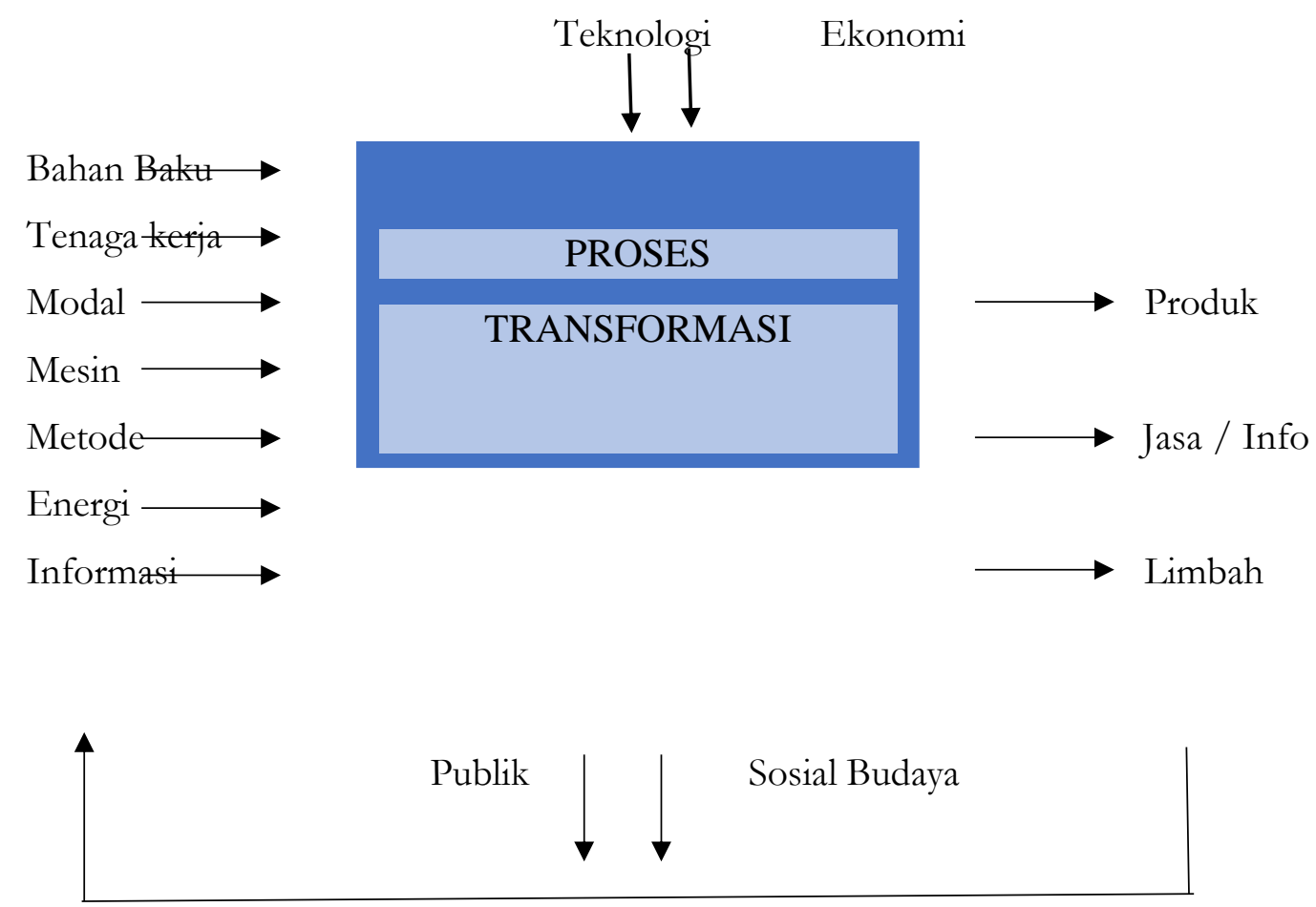

Umpan Balik / Feed Back

Bagan 1.1 Input Output Sistem Produksi 
Produksi yang baik dan berhasil ialah produksi yang dengan menggunakan empat faktor produksi yaitu: faktor alam, faktor tenaga kerja, dan faktor manajemen bisa menghasilkan barang sebanyak-banyaknya dengan kualitas semanfaat mungkin.

a. Faktor tanah atau alam

Dalam pandangan ekonomi klasik, tanah dianggap sebagai suatu faktor produksi penting mencakup semua sumber daya alam yang digunakan dalam proses produksi(Muhammad, 2004). Islam juga membolehkan pemilikan tanah dan sumbersumber alam yang lain dan membolehkan penggunaannya untuk beraktifitas produksi, dengan syarat hak miliknya merupakan tugas sosial dan khilafat dari Allah atas milik-Nya, dengan mengikuti perintah-perintah Tuhan dalam usaha memperoleh milik.

b. Faktor tenaga kerja

Manajemen sumber daya manusia menjadi fungsi yang semakin penting dalam suatu organisasi. Peran yang semakin penting tersebut disebabkan antara lain karena perubahan pandangan terhadap karyawan. Kalau dulu karyawan dianggap sebagai salah satu faktor produksi, seperti mesin, dimana biaya produksi termasuk gaji karyawan cenderung ditekan untuk mendorong efisiensi, maka pandangan yang lebih populer saat ini menganggap karyawan sebagai salah satu partner untuk mencapai tujuan organisasi. Disamping perubahan pandangan terhadap karyawan, peranan karyawan yang semakin penting juga disebabkan karena beberapa hal, seperti kompetisi yang semakin tajam, perubahan sosial dan perubahan perundangundangan(Hanafi, 2003).

Faktor tenaga kerja dalam aktivitas produksi merupakan upaya yang dilakukan manusia, baik berupa kerja pikiran maupun kerja jasmani atau kerja pikir sekaligus jasmani dalam rangka menghasilkan barang-barang dan jasa ekonomi yang dibutukan masyarakat. Adam smith mengatakan bahwasanya tenaga kerja itulah satu-satunya faktor produksi. Karena dengan tenaga kerjanya manusia dapat merubah apa yang terdapat pada alam. Dalam kaitanya dengan masalah tenaga kerja, Islam mengangkat nilai tenaga kerja dan menyuruh orang bekerja, baik bekerja untuk mencapai penghidupan yang layak dan menghasilkan barang-barang serta jasa yang menjadi keperluan manusia, maupun amal yang bersifat ibadah semata-mata kepada Allah.

c. Faktor modal

Modal adalah kekayaan yang memberi penghasilan kepada pemiliknya. Atau kekayaan yang menghasilkan suatu usaha yang akan digunakan untuk menghasilkan suatu kekayaan lain(Muhammad, 2004). Di dalam sistem Islam modal adalah amanah dari Allah yang wajib dikelola secara baik. Manusia atau para pengusaha hanya diamanahi Allah untuk mengelola harta atau modal itu sehingga modal itu dapat berkembang.

d. Faktor manajemen atau organisasi 
Manajemen sebagai salah satu faktor produksi, merupakan penaungan segala unsur-unsur produksi dalam suatu usaha produksi. Manajemen adalah upaya mulai sejak timbulnya ide usaha dan barang apa yang ingin diproduksi, berapa dan kualitasnya bagaimana. Islam menyuruh melakukan manajemen dan mengharuskan kepada manajer untuk mengikuti jalan keadilan dan menjauhi jalan yang akan membahayakan masyarakat. Atas dasar tersebut manajer Islam mengharamkan untuk mengatur produksi barang-barang yang haram dan tidak membolehkan perencanaan produksi barang-barang seperti ini. Dalam proses produksi melibatkan sejumlah orang (tenaga kerja) dari berbagai tingkatan, maka manajemen berarti pula mengelola orang-orang tersebut dalam tingkatan atau dalam tahapan proses produksi(Soekarwati, 2003).

\section{SISTEM PRODUKSI DALAM PERSPEKTIF EKONOMI ISLAM}

Berproduksi dalam Islam merupakan ibadah, sebagai seorang muslim berproduksi sama artinya dengan mengaktualisasikan keberadaan hidayah Allah yang telah diberikan kepada manusia. Hidayah Allah bagi seseorang muslim berfungsi untuk mengatur bagaimana ia mengelola produksi untuk sebuah kebaikan dan apapun yang Allah berikan kepada manusia merupakan sarana yang menyadarkan fungsinya sebagai seorang khalifah(Hasan, 2009).

Nilai-nilai dan norma dalam berproduksi, sejak dari kegiatan mengorganisasi faktor produksi, proses produksi hingga pemasaran dan pelayanan kepada konsumen, semuanya harus mengikuti moralitas Islam. Metwally mengatakan, bahwa perbedaan dari perusahaanperusahaan non-Islam tak hanya pada tujuannya, tetapi juga pada kebijakan-kebijakan ekonomi dan startegi pasarnya(Rivai, 2012). Produksi barang dan jasa yang dapat merusak moralitas dan menjauhkan manusia dari nilai-nilai religius tidak akan diperbolehkan.

Prinsip dasar ekonomi Islam adalah keyakinan kepada Allah sebagai Rabb dari alam semesta. Dengan keyakinan akan peran dan kepemilikan absolut dari Allah semesta alam, maka konsep produksi didalam ekonomi Islam tidak semata-mata bermotif maksimalisasi keuntungan dunia, tetapi lebih penting untuk mencapai maksimalisasi keuntungan akhirat(Nasution, 2007). Allah SWT berfirman dalam Quran Surat al Qhasash:77.

"Dan carilah (pahala) negeri akhirat dengan apa yang telah dianugerahkan Allah kepadamu, tetapi janganlah kamu lupakan bagianmu dari dunia dan berbuat baiklah (kepada orang lain) sebagaimana Allah telah berbuat baik kepadamu, dan janganlah kamu berbuat kerusakan di (muka) bumi. Sesungguhnya Allah tidak menyukai orang-orang yang berbuat kerusakan."

Bagi Islam, memperoduksi sesuatu bukanlah sekedar untuk dikonsumsi sendiri atau dijual kepasar. Dua motivasi itu belum cukup karena masih terbatas pada fungsi ekonomi. Islam secara khas menekankan bahwa setiap kegiatan produksi harus pula mewujudkan fungsi sosial(Nasution, 2007). Kita harus melakukan hal itu karena memang dalam sebagian harta kita melekat hak orang miskin, baik yang meminta maupun tidak meminta. Agar mampu mengemban fungsi sosial seoptimal mungkin, kegiatan produksi harus melampaui surplus untuk mencukupi keperluan konsumtif dan meraih keuntungan financial, sehingga bisa berkontribusi kehidupan sosial. 
Melalui konsep inilah, kegiatan produksi harus bergerak diatas dua garis optimalisasi. Tingkat optimal pertama adalah mengupayakan berfungsinya sumber daya insan kearah pencapaian kondisi full employment, dimana setiap orang bekerja dan menghasilkan suatu karya kecuali mereka yang 'udzur syar'i seperti sakit atau lumpuh. Optimalisasi berikutnya adalah dalam hal memproduksi kebutuhan primer, lalu kebutuhan sekunder dan kebutuhan tersier secara proporsional. Tentu saja Islam harus memastikan hanya memproduksi sesuatu yang halal dan bermanfaat buat masyarakat. Sebagai modal dasar berproduksi, Allah telah menyediakan bumi beserta isinya bagi manusia, untuk diolah bagi kemaslahatan bersama seluruh umat manusia.

Dalam memandang tenaga kerja, Islam berada pada posisi moderat. Faktor tenaga kerja, bekerja dan berusaha adalah penting, namun bekerja dan berusaha haruslah sejalan dengan yang halal dan pekerja perlu dijaga harkat dan martabatnya dan tidak bisa hanya dipandang semata-mata hanya sebagai faktor produksi saja. Seorang majikan yang memperkerjakan buruh tanpa memberi imbalan maka orang tersebut telah memperbudaknya. Memperlakukan buruh seharusnya bersifat humanis dengan memperhatikan hak-hak dasarnya dengan tidak memposisikan semata-mata sebagai faktor produksi yang bersifat maknistik. Oleh karena itu Islam sangat memperhatikan hak buruh untuk bisa beristirahat baik untuk memnuhi hak-hak anggota tubuhnya maupun hak berkaitan dengan orang lain misalnya hak untuk berkeluarga(Ridwan, 2007).

Adapun kaidah-kaidah dalam berproduksi(Nasution, 2007) antara lain:

1. Memproduksi barang dan jasa yang halal pada setiap tahapan produksi.

Prinsip etika dalam produksi yang wajib dilaksanakan oleh setiap muslim baik individu ataupun komunitas adalah berpegang pada semua yang dihalalkan Allah dan tidak melewati batas(Qardhawi, 1997).

2. Mencegah kerusakan dimuka bumi, termasuk membatasi polusi, memlihara keserasian dan ketersediaan sumber daya alam.

Etika yang terpenting adalah menjaga sumber daya alam karena ia merupakan nikmat dari Allah kepada hamba-Nya. Setiap hamba wajib mensyukurinya dan salah satu cara mensyukurinya adalah dengan menjaga sumber daya alam.

3. Produksi dimaksudkan untuk memenuhi kebutuhan individu dan masyarakat serta mencapai kemakmuran. Kebutuhan yang harus dipenuhi harus berdasarkan prioritas yang ditetapkan agama, yakni terkait dengan kebutuhan untuk tegaknya akidah dan agama, terpeliharanya nyawa, akal dan keturunan atau kehormatan, serta untuk kemakmuran material.

4. Produksi dalam Islam tidak dapat dipisahkan dari tujuan kemandirian umat. Untuk itu hendaknya umat memiliki berbagai kemampuan, keahlian dan prasarana yang memungkinkan terpenuhinya kebutuhan spiritual dan material. Juga terpenuhinya kebutuhan pengembangan peradaban, dimana dalam kaitan tersebut para ahli fiqih memandang bahwa pengembangan dibidang ilmu, industry, perdagangan, keuangan 
merupakan fardhu kifayah yang dengannya manusia bisa melaksanakan urusan agama dan dunianya.

5. Meningkatkan kualitas sumber daya manusia baik kualitas spiritual maupun mental dan fisik.

\section{HASIL DAN PEMBAHASAN}

\section{Perencanaan Sistem Produksi}

Dari 16 kerajinan bambu wulung, hanya membatasi pada 3 industri kerajinan bambu wulung yang sudah cukup maju dan mempunyai beberapa karyawan yang membantu usahanya, yaitu industri kerajinan bambu wulung milik Bapak Triyoko, Bapak Bambang dan Bapak Sahid. Perencanaan sistem produksi yang dilakukan oleh ketiga industri kerajinan bambu wulung di Desa Kemutug Kidul Kecamatan Baturraden Kabupaten banyumas meliputi:

a. Perencanaan Produk

Perencanaa produk merupakan perencanaan tentang produk apa, berapa dan bagaimana yang akan dapat diproduksikan oleh ketiga industri kerajinan bambu wulung Desa Kemutug Kidul, Baturraden. Produk yang diproduksi di industri tersebut berupa dipan, meja kursi set biasa dan meja kursi set ukir. Produk yang paling banyak diproduksi pada industri bambu wulung adalah dipan, karena untuk meja kursi set baik yang biasa ataupun yang ukir hanya diproduksi pada saat ada pesanan.

Jumlah kerajinan yang diproduksi setiap industri kerajinan berbeda-beda. Pada industri kerajinan bambu wulung milik Bapak Triyoko, dipan yang diproduksi minimal 20 perhari. Sedangkan pada industri kerajinan bambu wulung milik Bapak Bambang dan Bapak Sahid dipan yang diproduksi lebih dari 10 perhari. Hal ini terjadi karena jumlah dari karyawan yang membantu dalam proses produksi berbeda-beda. Waktu yang diperlukan dalam proses produksi untuk satu dipan adalah 2 jam. Untuk satu set meja dan kursi ukir dibutuhkan waktu 7 hari.

b. Perencanaan Lokasi Pabrik

Pabrik adalah tempat dimana fungsi teknis dari suatu perusahaan tersebut berada. Pemilihan lokasi pabrik yang tepat akan dapat menunjang kegiatan-kegiatan yang dilaksanakan oleh perusahaan sehingga potensi untuk mendapatkan keuntungan menjadi semakin besar. Ketiga pemilik industri memilih untuk membuka usahanya di Desa Kemutug Kidul Baturraden karena Desa Kemutug Kidul menjadi salah satu sentra industri bambu di Kabupaten Banyumas.

Selain sudah menjadi sentra industri bambu, letak tempat usaha yang berdekatan dengan objek wisata Baturraden juga menjadi salah satu alasan pemilihan tempat usaha. Dengan tempat usaha yang dekat dengan objek wisata akan mempermudah pemasaran hasil kerajinan karena akan banyak wisatawan yang berkunjung ke objek wisata Baturraden. Meskipun Desa Kemutug Kidul bukan menjadi tempat penghasil 
bambu wulung namun bukan menjadi kendala, karena bahan baku sudah didapat dari pemasok yang berasal dari kebumen, Purworejo, Bumiayu, Karang Pucung, Tegal dan Purworejo.

c. Perencanaan Letak Fasilitas Produksi

Penyusunan letak fasilitas produksi yang teratur serta memenuhi persyaratan teknis yang telah ditentukan akan menunjang adanya efisiensi kerja serta efektivitas pelaksanaan kegiatan dalam perusahaan yang bersangkutan. Pada ketiga industri kerajinan bambu wulung Desa Kemutug Kidul penyusunan letak fasilitas produksi disesuaikan dengan urutan proses produksi dan masih dalam satu tempat, hal tersebut dilakukan untuk mempermudah dalam proses produksi. Mulai dari letak produksi untuk pembagian tiap-tiap bagian dan pembuatan lobang pada bambu, kemudian tempat pembuatan belahan bambu untuk papan dan tempat perakitan selanjutnya letak tempat untuk finishing. Untuk tempat penyimpanan kerajinan yang sudah selesai dibuat terdapat di sebelah rumah pemilik industri kerajinan.

d. Perencanaan Lingkungan Kerja

Masalah lingkungan kerja dalam perusahaan terdapat tiga hal yang perlu untuk diperhatikan oleh manajemen perusahaan. Hal yang pertama adalah masalah pelayanan karyawan perusahaan. Ketiga industri kerajinan bambu wulung memberikan waktu istirahat untuk para karyawannya dan memberikan hari libur seminggu sekali setiap hari minggu serta tidak memaksa atau membebani karyawannya untuk bekerja melebihi kemampuannya.

Upah yang diberikan pemilik ketiga industri kerajinan kepaa karyawannya selalu tepat waktu. Untuk industri kerajinan bambu wulung milik Bapak Triyoko dan Bapak Bambang upah karyawan diberikan setiap satu minggu sekali yaitu setiap hari sabtu. Sedangkan bapak Sahid memberikan kebebasan kepada karyawannya untuk menentukan waktu pembayaran upah sesuai dengan yang dibutuhkan karyawannya. Hal ini dilakukan untuk menumbuhkan kepuasan kerja para karyawannya yang nantinya akan menimbulkan motivasi kerja.

Masalah yang kedua yang perlu mendapat perhatian dalam hal ini adalah kondisi kerja dari para karyawan. Suara yang tidak bising dan penerangan yang baik sangat membantu karyawan dalam melakukan produksi. Persoalan yang ketiga adalah masalah hubungan karyawan dalam perusahaan tersebut. Bapak Triyoko memilih untuk ikut kegiatan proses produksi untuk menciptakan kekeluargaan dan kerjasama yang baik antara pemilik industri dan karyawannya. Walaupun kedua pemilik industri kerajinan yang lain tidak ikut dalam kegiatan produksi namun tidak mengurangi sikap kekeluargaan antara pemilik dan karyawan. Adanya sikap kekeluargaan dan kerjasama yang baik diantara pemilik dan karyawan dapat menciptakan lingkungan kerja yang nyaman dan dapat mempengaruhi motivasi kerja para karyawannya.

e. Perencanaan Standar Produksi 
Adanya standar produksi dalam perusahaan, para karyawan akan mempunyai pegangan dalam pelaksanaan proses produksi. Karena produk yang dihasilkan ketiga industri kerajinan bambu wulung adalah untuk persediaan atau untuk pasar maka variasi dari desain, bentuk dan ukuran produk pada umumnya sama. Standar produksi yang membedakan dari ketiga industri kerajinan bambu wulung adalah proses finishing. Pada industri kerajinan bambu wulung milik Bapak Bambang dan Bapak Sahid standar produksi yang dihasilkan tanpa melalui proses pemberian cat vernis, sedangkan pada industri kerajinan milik Bapak Triyoko melalui proses pemberian cat vernis.

\section{Proses Produksi}

Dalam proses produksi kerajinan bambu wulung ada beberapa proses atau tahapan yang harus dilakukan, tahapan-tahapannya antara lain:

a. Tahap persiapan bahan baku dan bahan penunjang

Tahap persiapan bahan baku merupakan tahap awal dalam memulai kegiatan proses produksi kerajinan bambu wulung. Bahan dasar kerajinan yang dibuat yaitu bambu wulung hitam. Persiapan yang dilakukan adalah dengan mempersiapkan bahan baku, peralatan dan perlengkapan yang dibutuhkan dalam proses produksi.

b. Proses produksi

Sebagian besar pengrajin bambu memakai tahapan produksi dimulai dari perancangan kerajinan, membuat kerangka, diikat memakai tali rotan, menyusun iratan alas dan sandaran kursi atau meja. Setelah itu memasuki tahap akhir yaitu mengamplas dilanjutkan dngan pemberian vernis dan melamin agar kerajinan tampil elegan. Kemudian keringkan kerajinan supaya siap untuk dipasarkan.

1) Pembagian tiap-tiap bagian dan membuat lobang pada bambu

Dalam proses produksi langkah awal yang dilakukan adalah dengan membagi tiap-tiap bagian. Dalam tahap ini pengrajin harus benar-benar teliti karena perlu perhitungan yang tepat dalam ukuran maupun pembuatan lubang untuk sendi atau siku. Untuk membuat satu set kursi diperlukan sekitar 10 batang bambu. Sedangkan untuk membuat satu buah dipan hanya diperlukan 1 sampai 2 batang bambu.

Batang bambu yang telah diukur untuk masing-masing bagian dalam rangka mebel akan dipotong dengan menggunakan gergaji kayu. Batang bambu dengan diameter terbesar (bagian bawah bambu) difungsikan sebagai kaki kursi, karena bagian ini memiliki ketebalan batang paling besar sehingga memiliki kekuatan yang paling besar pula.

2) Pembuatan belahan bambu untuk papan

Bambu dipotong sesuai ukuran yang diinginkan kemudian dibelah, belahan bambu tersebut biasanya berukuran lebar sekitar $2 \mathrm{~cm}$. Belahan bambu tersebut kemudian disusun hingga berbentuk seperti papan atau dinding.

3) Perakitan 
Proses perakitan kerajinan bambu dimulai dengan pekerjaan memasukan bambu kedalam bagian-bagian yang telah dilubangi. Ukuran lobang harus disesuaikan dengan ukuran batang bambu yang akan dimasukan agar rangka kursi tidak bergoyang dan proses ini harus dilakukan dengan hati-hati agar bambu tidak retak dan rangka kaki dapat berdiri dengan kokoh.

Untuk memperkuat posisi sudut-sudut rangka yang telah dipasang maka dilakukan pengikatan dengan menggunakan tali rotan untuk meja kursi set dan tali biasa untuk dipan. Pengikat tali rotan ini selain untuk memperkuat posisi sudut rangka juga memberikan sentuhan seni yang dapat meningkatkan nilai jual produk. Setelah rangka kuat kemudian susunan belahan bambu pada alas duduk ditata sejajar dan diikat tali rotan dan diikatkan ke batang bambu yang dipasang dibawah susunan belahan bambu tersebut sehingga masing-masing belahan bambu dapat terikat dengan erat.

4) Finishing

Proses finishing dilakukan apabila seluruh proses perakitan sudah selesai dilaksanakan dan telah mendapat pengecekan dari pengrajin. Proses finishing yang dilakukan meliputi kegiatan mengamplas dan memberi vernis atau melamin. Mengamplas dilakukan agar bambu lebih halus. Cara mengamplas tidak boleh terlalu keras karena bisa merusak warna bambu yang alami.

Setelah diamplas kemudian bambu diberi vernis atau melamin pada seluruh lapisan bambu menggunakan kuas, dengan maksud untuk mempercantik kerajinan serta memberikan lapisan kepada kulit bambu agar kuat dan tahan lama atau awet. Setelah proses finishing dilakuakan, kerajinan bambu tidak boleh terkena sinar matahari langsung karena akan memudahkan terjadinya pecahpecah pada lapisan yang telah di vernis atau melamin. Vernis atau melamin akan kering dalam waktu 2-3 jam dan kerajina siap untuk dijual.

\section{ANALISIS EKONOMI ISLAM TERHADAP SISTEM PRODUKSI DI INDUSTRI KERAJINAN BAMBU WULUNG}

Dalam Islam memproduksi harus sesuai dengan prinsip etika dalam produksi yaitu berpegang pada semua yang dihalalkan Allah dan tidak melewati batas. Selain menjaga tingkat kualitas output tetapi kualitas proses yang dilakukan juga harus sesuai dengan ajaran-ajaran Islam. Sistem produksi dapat dilihat dari 3 bagian yaitu input, proses dan output. Berdasarkan paparan diatas maka sistem produksi industri kerajinan bambu wulung desa Kemutug Kidul, Baturraden, Banyumas yang sesuai dengan perspektif ekonomi Islam yaitu:

1. Input

a. Sumber Daya Alam atau Bahan Baku

Sebagai modal dasar berproduksi Allah telah menyediakan bumi beserta isinya bagi manusia untuk diolah bagi kemaslahatan bersama seluruh umat manusia. Sumber daya alam atau bahan baku yang digunakan oleh industri kerajinan bambu 
wulung adalah bambu yang berwarna hitam. Pemanfaatan bambu wulung yang digunakan oleh industri kerajinan bambu wulung digunakan sesuai kebutuhan yang diperlukan dan didayagunakan sebaik-baiknya agar bambu yang digunakan tidak terbuang. Dalam memanfaatkan bambu juga tidak boleh mengeksploitasi secara berlebihan. Hal ini sesuai dengan Firman Allah dalma surat Al-A'raf ayat 56.

Sumber daya alam merupakan nikmat dari Allah kepada hambanya, maka dalam ayat diatas menjelaskan bahwa setiap hamba wajib mensyukurinya. Salah satu cara mensyukuri nikmat adalah dengan menjaga sumber daya alam dari polusi, kehancuran dan kerusakan. Bambu wulung yang digunakan adalah bambu wulung yang warnanya sudah benar-benar hitam dan batang dengan ukuran yang besar, karena akan dijadikan penopang atau kaki kursi. Hal tersebut dilakukan agar tidak merusak tanaman bambu yang lain yang masih dapat tumbuh dengan baik.

b. Sumber Daya Modal

Modal adalah kekayaan yang memberikan penghasilan kepada pemiliknya. Harta dan kekakayaan harus digunakan sebaik mungkin, sehingga penggunaan suatu materi juga harus dipertimbangkan dengan baik dan benar. Menurut Islam, harta pada hakikatnya adalah hak milik Allah. Namun karena Allah menyerahkan kekuasaannya atas harta tersebut kepada manusia, maka perolehan seseorang terhadap harta itu sama dengan kegiatan yang dilakukan oleh seseorang untuk memanfaatkan serta mengembangkan hartanya. Pemilik tiga industri kerajinan bambu wulung Desa Kemutug Kidul, Baturraden, Banyumas memanfaatkan serta mengembangkan hartanya untuk melakukan usaha kerajinan bambu wulung yang sesuai dengan hukum-hukum Islam. Selain itu, dalam Islam sumber modal tidak boleh berasal dari harta yang haram. Begitupun pada ketiga industri kerajinan bambu wulung yang sumber modalnya sepenuhnya berasal dari harta pribadi tanpa pinjaman.

c. Sumber Daya Manusia

Dalam pemilihan tenaga kerja ketiga industri kerajinan bambu wulung tidak memiliki kriteria khusus, karena kebanyakan karyawannya adalah warga didaerah sekitar industri yang sudah memiliki ketrampilan dalam kerajinan bambu wulung. Dalam kegiatan produksi Bapak Triyoko memilih untuk ikut langsung dalam kegiatan produksinya agar lebih dekat dengan para karyawannya sehingga akan lebih tercipta kekeluargaan dan kerjasama yang baik. Sedangkan kedua pemilik industri kerajinan yang lain tidak ikut dalam kegiatan produksi namun tidak mengurangi sikap kekeluargaan antara pemilik dan karyawan. Adanya sikap kekeluargaan dan kerja sama yang baik diantara pemilik dan karyawan dapat menciptakan lingkungan kerja yang nyaman dan dapat mempengaruhi motivasi kerja para karyawan.

Setiap karyawannya mempunyai bagian-bagian sendiri seperti yang telah dijelaskan sebelumnya, sehingga pekerjaan yang dilakukan akan saling bersinergis dan membuahkan hasil yang maksimal. Ketiga industri kerajinan bambu wulung juga memberikan waktu istirahat untuk para karyawannya dan memberikan hari libur seminggu sekali setiap hari minggu serta tidak memaksa atau membebani 
karyawannya untuk bekerja melebihi kemampuannya. Hal ini sesuai dengan firman Allah dalam surat Al-Baqarah ayat 286.

Dalam hal pemberian upah kepada karyawannya ketiga industri bambu wulung memiliki sistem yang berbeda. Untuk industri kerajinan bambu wulung milik Bapak Triyoko dan Bapak Bambang upah karyawan diberikan setiap satu minggu sekali yaitu setiap hari sabtu. Sedangkan industri kerajinan bambu wulung milik Bapak Sahid memberikan kebebasan kepada karyawannya untuk menentukan waktu pembayarannya sesuai dengan yang dibutuhkan karyawannya. Hal ini sesuai dengan sabda Rasulullah: Berikanlah upah pekerja sebelum keringatnya kering.

2. Proses Produksi

Proses produksi untuk menghasilka keluaran, baik produk barang maupun jasa mempunyai beberapa bentuk. Sebelum melakukan proses produksi terlebih dahulu mempersiapkan bahan baku dan peralatan yang dibutuhkan pada saat proses produksi berlangsung. Alat ynag digunakan untuk membuat kerajinan merupakan alat atau bahan yang bersih, yang mana dalam Islam barang tersebut dibolehkan untuk dipakai. Allah sangat mencintai aktivitas atau perbuatan yang terorganisir dengan baik, karena apabila suatu kegiatan terorganisir dengan baik dan diantara bagian-bagiannya tersusun dengan rapi dan kokoh dan saling sinergis maka akan membuahkan hasil yang memuaskan dan maksimal.

Proses produksi yang dilakukan oleh ketiga industri kerajinan bambu wulung sesuai dengan tahapan-tahapan yang telah direncanakan. Selama proses produksi ketiga pemilik industri kerajinan juga selalu memberikan arahan dan tidak segan untuk menegur karyawannya apabila terjadi hal yang tidak sesuai. Dimana dengan arahan yang baik diharapkan akan memperlancar proses produksi sehingga akan meminimalisir kegagalan dalam proses produksi.

3. Output

Setelah input (sumber daya produksi) yang diolah melalui proses produksi maka akan menghasilkan output berupa barang. Barang yang dihasilkan tergantung pada kualitas pada saat proses produksi. Oleh karena itu ketiga industri kerajinan bambu wulung sangat memperhatikan proses produksi yang dilakukan tahapan demi tahapannya. Sehingga produk akhir yang dihasilkan adalah produk yang bebas cacat dan tidak ada lagi pemborosan yang harus dibayar mahal karena produk tersebut harus dibuang atau dilakukan pengerjaan ulang.

Produk yang dihasilkan oleh industri kerajinan bambu wulung Desa Kemutug Kidul, Baturraden berkualitas baik. Hal ini dibuktikan dengan respon yang tinggi dari masyarakat luas. Ketiga industri kerajinan bambu wulung selalu memberikan hal yang terbaik untuk para konsumennya. Melalui pengawasan yang dilakukan pada proses produksi dan sumber daya produksi yang baik sehingga dapat menghasilkan produk yang berkualitas. 


\section{KESIMPULAN}

Berdasarkan hasil penelitian atau pengamatan yang dilakukan oleh penulis di industri kerajinan Bambu Wulung Desa Kemutug Kidul, baturraden, Banyumas maka penulis menyimpulkan bahwa industri Kerajinan Bambu Wulung Desa Kemutug Kidul, baturraden, Banyumas sebagian telah menerapkan sistem produksi sesuai dengan perspektif Ekonomi Islam. Sistem produksi kerajinan perspektif ekonomi Islam yang diterapkan di industri kerajinan bambu wulung Desa Kemutug Kidul, baturraden, Banyumas dapat dilihat mulai dari input, proses produksi hingga output.

Pada input dapat dilihat dari sumber daya alam atau bahan baku, sumber daya modal dan sumber daya manusia. Dalam hal bahan baku dapat dilihat dari pemanfaatan bambu wulung yang digunakan sesuai dengan kebutuhan yang diperlukan dan didayagunakan sebaik-baiknya Modal yang digunakan adalah modal yang berasal dari harta pribadi yang halal sehingga dapat dimanfaatkan dan dikembangkan untuk usaha kerajinan bambu wulung. Dari aspek tenaga kerja, ketiga industri kerajinan bambu wulung memberikan waktu istirahat untuk para karyawannya dan memberikan hari libur satu minggu sekali serta tidak memaksa atau membebani karyawannya untuk bekerja melebihi kemampuannya. Pemilik industri kerajinan dalam memberi upah kepada karyawannya selalu tepat waktu.

Proses produksi yang dilakukan oleh ketiga industri kerajinan bambu wulung Desa Kemutug Kidul dilakukan sesuai dengan tahapan-tahapan yang telah direncanakan. Pada output dilihat dari produk yang dihasilkan oleh industri kerajinan bambu wulung Desa Kemutug Kidul, Baturraden tentunya berkualitas baik. Hal ini dibuktikan dengan respon yang tinggi dari masyarakat luas. Ketiga industri kerajinan bambu wulung selalu memberikan hal yang terbaik untuk para konsumennya. Melalui pengawasan yang dilakukan pada proses produksi dan sumber daya produksi yang baik sehingga dapat menghasilkan produk yang berkualitas.

\section{DAFTAR PUSTAKA}

Ahyari, A. (1999). Manajemen Produksi Perencanaan Sistem Produksi. Yogyakarta: BPFEYogyakarta.

Arikunto, S. (1992). Manajemen Penelitian. Jakarta: Rineka Cipta.

Dwiyanto, A. (1996). Penduduk Dan Pembangunan. Yogyakarta: Aditya Media.

Et.al, C. D. K. (2019). Production Planning And Inventory Control. Yogyakarta: Penerbit Deepublish.

Hanafi, M. M. (2003). Manajemen. Yogyakarta: UPP AMP YKPN.

Hasan, A. (2009). Manajemen Bisnis Syariah. Yogyakarta: Pustaka Pelajar.

Karamoy, R. P., Tumade, P., \& Palandeng, I. D. (2016). Implementasi Sistem Produksi Pada Industri Kecil Menengah ( Studi Kasus Pada: Industri Kecil Menengah “ Ikm ” Di 
Desa Touliang Oki ) ( Case Study : Small Medium Industry At Touliang Oki ).

Moleong, L. J. (2008). Metode Penelitian Kualitatif. Bandung: Remaja Rosdakarya.

Muhammad. (2004). Ekonomi Mikro Dalam Perspektif Islam. Yogyakarta: BPFE-Yogyakarta.

Nasution, M. E. dkk. (2007). Pengenalan Eksklusif Ekonomi Islam. Jakarta: Kencana Prenada Media Group.

Qardhawi, Y. (1997). Norma dan Etika Ekonomi Islam. Jakarta: Gema Insani Press.

Ridwan. (2007). Fiqib Perburuban. Yogyakarta: Grafindo Litera Media.

Rivai, V. dkk. (2012). Islamic Bussines And Economic Ethnics. Jakarta: Bumi Aksara.

Soehartono, I. (2000). Metode Penelitian Sosial. Bandung: Remaja Rosdakarya.

Soekarwati. (2003). Teori Ekonomi Produksi. Jakarta: RajaGrafindo Persada.

Suryabrata, S. (1990). Metode Penelitian. Jakarta: Rajawali. 